\title{
Accomplice -Credible witness
}

\author{
Sufi Imdad Ali Soomro
}

\author{
DOI: 10.29322/IJSRP.11.10.2021.p11809 \\ http://dx.doi.org/10.29322/IJSRP.11.10.2021.p11809
}

\begin{abstract}
Accomplice is dealt under article 16 of the Qanoon-eShahadat, 1984. Though term Accomplice has not been explained in the Qanoon-E- Shahadat, 1984, and generally is viewed as a person who has taken part in the commission of crime along with wrong doers. This article through light about authenticity as well as admissibility of the accomplice in the court of law. Most of the time, accomplice evidence might seem to be untrustworthy and unreliable but often it comes out as an invaluable in solving the crime and delivering justice. Further, it will talk about the accomplice being a competent witness and how it differs from the co-accused.
\end{abstract}

Index Terms- Commission of Crime, Admissibility, Accomplice, Criminal Justice System, Additional Evidentiary Tool, Approver, Unworthy Person, Fair Trial, Judicial Prudence, Sufficiently Corroborated

\section{INTRODUCTION}

$\mathrm{T}$ he mainstay of the criminal justice system is to provide justice to all and sundry and give punishment to the accused after holding a free and fair trial. It is also a requisite condition of a criminal justice system, which the prosecution officer with support of investigation officer has to prove culpability beyond a reasonable doubt for punishing the accused and securing conviction. In the technology era, criminals are well equipped with sophisticated technology, and investigation and prosecution is facing daunting challenges to apprehend the culprits with credible evidence to prove their guilt beyond a reasonable doubt in the court of law. So additional tool ", accomplice" is being frequently adopted where investigations officers are not finding any lead or clue to make progress in the case. Eminent jurists are in the view that additional evidentiary tool has strengthened the judicial system to make sure that criminals should not escape from clutches of the legal process. The precept of approver was quite common in ancient time and generally took in the death penalty cases or when dissidence in such conditions state machinery needed to way to deal with the individuals who arraigned in treacheries or hostile to state case to admit and hack out subtleties of the offense and consequently, the acquittal could be conceded.

\section{RATIONAL ACCOMPLICE AS A WITNESS}

It can be easily understood that one of the major characteristics of this practice is to induce an accomplice to incriminate others either for conscientious approach, out of fear, or on the directions of the investigation officer in the hope of getting his own freedom. Jurists are in the view that the doctrine of approval provides an opportunity to the accomplice to introspect and timely divulge details of offence so as to facilitate and succor the investigation and judicial process to ensure justice. Trial courts as well as apex court have given innumerable decisions and has succinctly depicted the nature and scope of approver in the criminal justice process. An approver is a most unworthy person because for sake of immunity he has to prove his worthiness for credibility in the court. He has to present the story or minute details in a manner that the court should accept his version by corroborating other evidence in order to prove the guilt of the accused beyond a reasonable doubt.

\section{WHO IS AN ACCOMPLICE UNDER THE QANON-E- SHAHADAT ORDER \& CRIMINAL PROCEDURE CODE 1898 ?}

The word 'accomplice "has not been described either in the Code of Criminal Procedure (Cr. P.C 1898) or Qanoon-e-Shahadat Order 1984. Section 337 to 339-A of CRPC 1898, even do not use this term. However, the word "accomplice "has been used in section 16 and 129(b) of the Qanun-e Shahadat 1984. A careful perusal of section 337 and 338 of the CRPC 1898, will show that the definition of the expression "accomplice "contained in them in the general sense.

Both these sections lay down that a pardon can be tendered, under the provision of section 337, CRPC1898 to a person "supposed to have been directly or indirectly concerned in the privy of the offence ". In section 338 of CRPC for the word "the "italics, the word "such has been used. Resultantly, so that if any person who is seeking or agreed to speak out truth is eligible for a pardon Generally it is believed that he is either directly or indirectly involved in crime which is committed.

\section{WHO CAN BE AN ACCOMPLICE?}

The Black Law's Dictionary (Tenth Edition) describes "accomplice" as someone who is in any way involved with another in the commission of a crime, whether are as a principal in the first or second degree or as an accessory. Some who knowingly, voluntarily, and intentionally unites with the principal offender in committing a crime and thereby becomes punishable for it." The word accomplice has been defined in various decisions that are as follows; (An accomplice is a person who participates in crime with the accused but after the commission of the crime, out of fear or repentance, sides with the prosecution to obtain immunity from punishment. He is a co-conspirator in a crime or has a close enough relationship to the crime to be charged alongside the primary. This is an individual who claims to be complicit or who makes an admission of fact that e or she was deliberately involved in the crime. 


\section{IS WITNESS AN ACCOMPLICE OR NOT?}

The Federal Shariat Court, in its judgment titled Haider Hussain vs. Govt. Of Pakistan, interprets the word accomplice in the following words," An accomplice is co-accused, an associate or partner who has such relation to the criminal act that he (or she) can be jointly charged with the other accused." An accessory has been articulated as an ethical blackguard "and individual who has associated the offence or who makes confirmation or realities showing that he had a cognizant hand in. Where a witness is not worried about the commission of wrongdoing, he cannot be supposed to be an accessory and his assertion needs no certifications. It is settled rule that accomplices know that offence was committed, the accessory must have knowledge that accused committed offence and accessory harbor and provided assistance in that offence. The accomplice is a true preparator for all members of the base but cannot be regarded as an accomplice if he joins a conspiracy only for the purpose of identification of the crime and bringing the perpetrators to justice. As a result, a person is only an informant, and their testimony can be accepted without further investigation. The standard requiring validation does not have any significant bearing to witness individual who has taken an interest in, or even incited or induced the wrongdoing, as Police spies.

The reason for inciting such condition is not commission of offence nor the infringement of the law, but rather obtaining of proof which is requisite condition for the dispensing of justice. It is an admitted fact that case would influence dependability of witness that was employed by the investigation team / Police to work as spy. The simple truth that in individual is locked in to notice a wrongdoing does not make then complicit until they are demonstrated to play has an impact in the wrongdoing.

In America, it has already been established that a person who contacts criminals without even any criminal intent and simply discover them finding in an indictable offence is not an accomplice. (Com. Dowing, 4, Gray 29M; State Meckene 1873,26 Iowa 349 Am). It is true that Courts do not look with favor on the statements of the informers or agent provocateur, but they cannot be placed in the class of accomplice and the rule requiring corroboration does not apply to them. The weight to be accorded to the testimony of a specific witness of this category must be determined by the procedure established by law rather than by a patchwork of procedure.

\section{EVIDENTIARY VALUE OF AN ACCOMPLICE - THE NEED FOR CORROBORATION}

Evidence is one of the most important aspects of the trail, and it is a necessary condition of justice that the accused be given a fair trial. It is the central belief of the criminal justice system that innocent people should not be apprehended and, even if they are, should not be convicted for crimes they have not committed. Evidence is explained by eminent Jursit, Bentham a s" any matter of fact, the effect, tendency or design of which is to produce in the mind a persuasion affirmative or dis-affirmative of the existence of the existence of some other matter of fact. A witness is a person who has information about offense and individual either willingly, or under fear and threat discloses testimony evidence of what he or she knows, either verbally or in writing. It is well- known truth of no eyewitness or witness is present, the offender has considerably higher chance of escaping. The courts are determined to pronounce judgment on the basis of available evidence and give punishment to the accused on the basis of statement recorded by the witnesses and same corroborated and material to issue. The notion of corroboration of evidence provided by accomplice in the front of the did not emerge until the $18^{\text {th }}$ century, when courts began to recognize that evidence produced by the accessory must be corroborated with an independent witness.

It is a fact that there are numerous cases in which criminals perpetrate crime in the well-planned or sophisticated manner or isolated places where it is least possibility of eyewitnesses to testify regarding such offences, and rather it would be hardly possible for the Police to gather enough or suffice evidence to prove the guilt of the accused. In such conditions, the investigation is constrained to seek the help of an accomplice. Article 16 of Qanun-e-Shahadat, 1984. Too, enactment gives that a conviction is not illegal on the grounds that depends on unverified proof of accessory and if the offence was punished by Hadd and the evidence of an accomplice was unfounded. Albeit article of the Qanun-e- Shahadat 1984, makes associates a competent witness, but article 129 gives space to the court to presume that "accomplice is unworthy of credit unless he is corroborated in material particulars. The terms, corroborations mean, independent testimony. It does not mean that minuscule details should be corroborated and all that is required by the court that additional testimony should be provided for rendering it probable that the story of the accessory is true. For example, in a case of anti-state or conspiracy, if there is corroboration with regards to postulate facts that conspiracy was designed with nefarious intention and involvement in it of any accused, so in such conditions corroborations of particular acts is unnecessary until the evidence of the accused is intrinsically subject to suspicious. Quantum of corroboration cannot be draw out in specific as it relies upon the circumstances; specially on the crime charged and degree of accessory complicity.

Furthermore, Rule 5 of chapter 14, Volume -III, High Court Rules \& Orders, also emphasizes that since evidence of approver is being an accomplice is prima facie of a suspect and doubtful character, so it should be scrutinized with caution and prudence. It adds, that an issue of law, straightforward as can be, conviction is terrible on flimsy grounds and it is rule of testimony that punishment should be decided upon facts and supported material. In this connection observations of Bashir-ud-din Ahmed, J, in "Din Muhammad Vs. The State may be quoted with profit. "His Lordship observed," The only evidence on the point is that of the Thannedar and since he was an accomplice being a decoy witness his statement cannot be relied upon without corroboration from an independent source. "See P. Venkata Roa Vs. King (1951Orissa 281). The relevant portion from the judgment runs:-"Where in a prosecution under 161 against a Station Master for accepting a bribe for supplying wagons to the complainant, the whole prosecution story is based upon the tainted evidence of decoy witnesses who are either accomplices or spies of the Police in a trap set up for the accused, it is unsafe to convict the accused unless there is some independent evidence either direct or circumstantial, to prove his guilt. 
It is clearly drawn out in section 337 and 338 Cr.P.C 1998, that it is Court Prudence to delicate exoneration to any blamed person and articulate him as approver relying in the prerequisite that the accused shall speak the truth and make genuine revelation of the offence as executed inside his insight and not coverup/ stifle any reality. In case of murder /injuries, which fall in the domain of Hadd and Diyaat,

It is clearly drawn out in areas 337 and 338 Cr. P.C that it is Court prudence to delicate exoneration to any blamed and articulate him an approver relying on the prerequisite that the denounced will talk reality and make genuine revelation of the offense as executed inside his insight and not cover up/stifle any reality. If there should arise an occurrence of homicide/wounds, which fall in the domain of Hadd and Diyaat, no individual will be acquitted without the consent of the person in question or lawful beneficiaries, as the case may be .

\section{Nature and Scope of Corroboration}

The courts are very much conscious that the accomplice's statement should not be of sufficient weight to award a sentence to the accused since the tendency for freedom by means of perjury is too great to permit such a statement. So, in this regard, Apex Court of Pakistan in the Federation of Pakistan Vs. Muhammad Shafi Muhammadi 1994 SCMR 932 has laid down guidelines that the standard of judiciousness that the declaration of an approver or associate is to be substantiated in material specifics by free proof has nearly solidified into rule of law, with the progression of time and because of the invariable insistence of the Superior Courts to have corroboration.

The evidential value of a witness's statements is determined by the type of the statements, the substance of the evidence, and the court's assessment of the testimony. Even a single statement may be considered adequate evidence, whereas a lengthy narration by the witness may not be considered a reality at all. This, however, is contingent on the. Value of a witness's testimonies, which has surfaced as a result of the investigation.

The criminal law has also given tremendous importance to examine an accomplice's credibility and dependability. It is true to say that while weighing the weight and worth of a witness's testimony, the appearance, attitude, and behavior of the witnesses, as well as the witness's interest in the outcome of the case, All other facts and circumstances in evidence, including the witness's relationship to the parties, his or her tendency to speak truthfully or not, the probability or improbability of the witness' assertions, and all other facts and circumstances in evidence, may be considered. Hence, it is solely reply upon the court if they decide or make up mind whether accomplice of worthy nature or not

Undoubtedly numerous complaints, for instance , competency and believability are reiterated by legal counsels and learned courts with the progression of time have perceived and realized through its judgments that there are certain flaws, genuine holes that unchallenged acknowledgment of the testimony of the one who is turning's state proof against his alleged partner in wrongdoing. It is reality that apprehended accused was captivated either by Police or out of dread was much of the time ready to get pardon by recoding the statements against the partners. It became highlighted through Sir, John Beaumont Sahu, PLD 1949, PC that withdrawal/ retraction of admittance of accused is an ordinary sample in India ------ the associate is very own confirmation a person of now no longer a great individual who did take part in crime and later on keep himself double crossed his preceding partners, and who has set himself in scenario wherein he can slightly to have a strong predisposition within side the blessing of indictment.

The main problem is that accessory tells a story in the most obvious way and it's easy for him to incorporate components of the story that are fake. It can involve ten people in a crime and the story can be valid in all respects by law, but dishonestly in the terms of the next two, whose names are given as supported opponents. As the honorable judges have pointed out more than once, this need to match the innocent with the insidious is so common in India that it is indeed a challenge for the courts to prepare for risk. There is no rigidity in determining what degree of confirmation is important to recognize from the associate Court will truly consider different factors, for example of the nature of wrong doing , approver's proof to the degree of his complicity ,and described realities relating to the wrongdoing. Legitimately, the language of article 129 (b) of Qanoon-e-Shahadat1984 is unequivocal and clear that "An accessory is a dishonorable credit except if he is certified in material specifics. The initial segment of the article relates to law and order while the subsequent part relates to the standard of reasonability. It does the trick to say or infer that the two articles are neither restricting nor conflicting, but instead complete one another.

The apex court of Pakistan, in its judgment named "Federation of Pakistan versus Muhammad Shafi (SCMR 932) held that "such of apparent conflict, the court is required to place such construction which may harmonize the two provisions". It is always incumbent upon the courts, and it is their discretion to rely upon the evidence of accomplice witnesses by applying judicial prudence as well examining all relevant facts. However, the cautious approach needs to be adopted while weighing the probative value of such evidence and the trial court is bound to carefully consider the factors in totality in which the pardon was tendered. Furthermore, in Indian Court, has rightly observed in Shanker vs. State of Tamil Nadu, the court held that when an accomplice becomes, an approver, he eventually becomes a prosecution witness. The approver's evidence must meet two sets, their evidence must be reliable, and secondly, their testimony must be sufficiently corroborated. Evidence from approvers should be examined with great care and caution. Courts have an onerous responsibility to be doubly sure that the approvers' evidence is corroborated by reliable evidence and is sufficient to prove guilt beyond reasonable doubt.

\section{CONCLUSION}

The learned courts of the country have by harmoniously reading 16 articles of Qaunn -e- Shahadat 1984, and section 129 together has set guiding principles with respect to accomplice evidence which explicitly lays down without any ambiguity. Through the lengthy trial process, the learned courts have set the principle that conviction produced based on uncorroborated evidence of an accomplice is not against the law but the rule of prudence and judicial wisdom it is not fair to act upon evidence as produced by accomplice without corroborated evidence to award any sentence to the accused. it is essential that the approver's statement has been corroborated with 
independent credible evidence so as to shorten the distance between crime and criminals it is hard fact that the approver is who betrayed his partners in the offence. Therefore, it is indispensable for dispensing of justice to not solely rely on the statement of an accomplice, without independent corroboration. It is also an admitted fact that article 16 of the Qanun-e Shahadat, 1984, is incorporated which does not bar or restrict conviction based on sole statement of an accomplice but as per law prudence, it Is not advisable.

\section{OBJECTIVE}

The purpose of this study is to examine the provisions of an accomplice witness as incorporated in laws. To evaluate relevant sections of Pakistan criminal Procedure Code and Qanoon -eShahadat 1984 Order in the light of court rulings. Look into case laws where court allowed to accept witnesses of accomplice and but set its limitations by allowing to corroborate evidences

\section{Research Methodology}

In this review article, the secondary data has been utilized to fill the research gap through a particular nature of research objective. This is a research article and all data collected is secondary data.

\section{$\mathrm{X}$. Discussions}

It shall provide academic material to the law readers and valuable input will provide an opportunity to open a window of discussion to form legal opinion in the light of case studies and court rulings.

\section{REFERENCES}

[1] Pakistan Penal Code 1860

[2] Pakistan Criminal Procedure Code 1898

[3] Qanun -e- Shahadat 1984

[4] Constitution of Pakistan 1973

[5] Black Law Dictionary ( Tenth volume )

[6] Website reference

[7] https://courtingthelaw.com/2018/01/15/commentary/is-an-accomplice-acredible-witness/

[8] https://sys.lhc.gov.pk/appjudgments/2019LHC4562.pdf

[9] http://www.oppapers.com/essays/A-Critical-Analysis-Of-AccompliceWitness $/ 507650$

[10] https://hamariweb.com/articles/103861

[11] http://legal-dictionary.thefreedictionary.com/Accomplice+Witness

[12] https://www.supremecourt.gov.pk/downloads_judgements/c.p._2243_1_201 9.pdf

[13] http://www.legalservicesindia.com/article/906/Accomplice-Witness-\&-itsadmissibility-as-Evidence.html

[14] https://scholarlycommons.law.northwestern.edu/cgi/viewcontent.cgi?article $=3610 \&$ context $=$ jclc.

[15] Case Referred:

[16] Haider Hussain vs. Govt. Of Pakistan

[17] "Din Muhammad Vs. The State

[18] P. Venkata Roa Vs. King (1951Orissa 281)

[19] Federation of Pakistan Vs. Muhammad Shafi Muhammadi 1994 SCMR 932

\section{AUTHORS}

First Author - SUFI IMDAD ALI SOOMRO 